\title{
A Small Synthetic Molecule Forms Chloride Channels to Mediate Chloride Transport across Cell Membranes
}

\author{
Xiang $\mathrm{Li}^{\dagger}$, Bing Shen ${ }^{\S}$ Xiao-Qiang $\mathrm{Yao}^{\S}$ and Dan Yang ${ }^{\dagger *}$ \\ ${ }^{\dagger}$ Department of Chemistry, The University of Hong Kong, Pokfulam Road, Hong Kong, \\ China \\ ${ }^{\S}$ Department of Physiology, The Chinese University of Hong Kong, Shatin, N.T., Hong \\ Kong, China
}

\section{Preparation and characterization of compound 1}
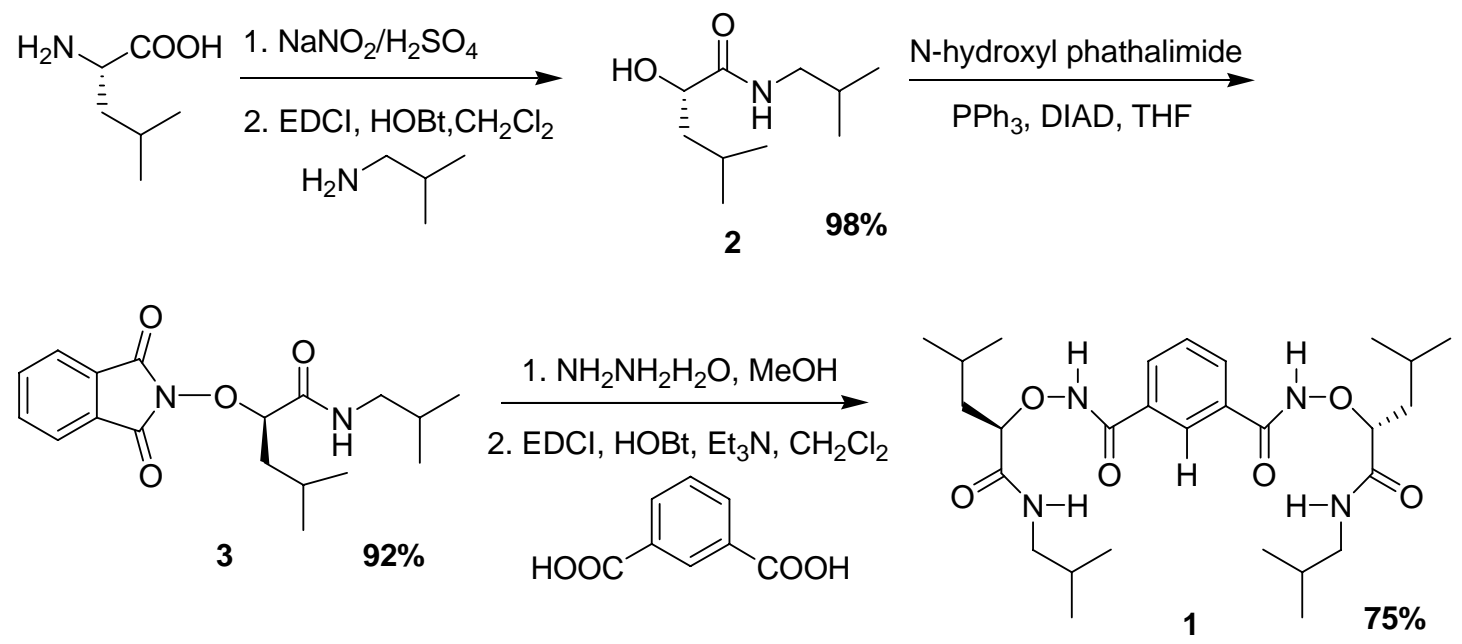

Concentrated sulphuric acid $(0.48 \mathrm{~mL})$ was added cautiously to water $(22 \mathrm{~mL})$ in a $100 \mathrm{~mL}$ round-bottom flask containing L-leucine $(787 \mathrm{mg}, 6.0 \mathrm{mmol})$. A solution of $\mathrm{NaNO}_{2}(1.24 \mathrm{~g}, 18 \mathrm{mmol})$ in water $(40 \mathrm{~mL})$ was added through a dropping funnel at such a rate that the temperature of the reaction mixture did not exceed $5{ }^{\circ} \mathrm{C}$. After stirred at 0 ${ }^{\circ} \mathrm{C}$ for 1 hour, the reaction mixture was slowly warmed to room temperature and stirred for another 1 hour. The product was extracted with ethyl acetate and the organic layer was washed with brine and then dried over anhydrous $\mathrm{MgSO}_{4}$. The organic solvent was evaporated off to give sticky light yellow oil, which was used directly in the next step.

Freshly distilled $\mathrm{CH}_{2} \mathrm{Cl}_{2}(50 \mathrm{~mL})$ was added to a flask containing the above yellow 
oil under nitrogen atmosphere, followed by the addition of HOAt (1.06 g, $7.8 \mathrm{mmol})$, isobutylamine $(0.63 \mathrm{~mL}, 6.3 \mathrm{mmol})$, and finally EDCI (2.68 g, $9.0 \mathrm{mmol})$. After being stirred overnight, the reaction mixture was diluted with $\mathrm{CH}_{2} \mathrm{Cl}_{2}$. The organic layer was washed with $5 \% \mathrm{NaHCO}_{3}$ and brine, then dried over anhydrous $\mathrm{MgSO}_{4}$ and concentrated. The crude oil was purified by flash column chromatography to afford compound $2(1.1 \mathrm{~g}$,

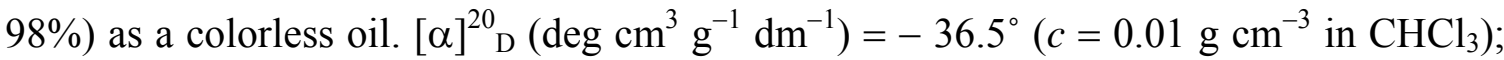
${ }^{1} \mathrm{H}-\mathrm{NMR}\left(300 \mathrm{MHz}, \mathrm{CDCl}_{3}\right) \delta 6.50(\mathrm{br}, 1 \mathrm{H}), 4.17-4.11(\mathrm{~m}, 1 \mathrm{H}), 3.14-3.08(\mathrm{~m}, 2 \mathrm{H}), 2.49$ $(\mathrm{d}, J=5.0 \mathrm{~Hz}, 1 \mathrm{H}), 1.83-1.53(\mathrm{~m}, 4 \mathrm{H}), 0.97(\mathrm{~d}, J=6.6 \mathrm{~Hz}, 6 \mathrm{H}), 0.92(\mathrm{~d}, J=6.6 \mathrm{~Hz}, 6 \mathrm{H})$; ${ }^{13} \mathrm{C}-\mathrm{NMR}\left(125 \mathrm{MHz}, \mathrm{CDCl}_{3}\right) \delta$ 174.15, 70.87, 46.42, 44.06, 28.55, 24.61, 23.49, 21.42, 20.07, 20.06; IR $\left(\mathrm{CHCl}_{3}\right)$ 3425, $1662(\mathrm{C}=\mathrm{O}) \mathrm{cm}^{-1}$; LRMS (EI, $\left.20 \mathrm{eV}\right) \mathrm{m} / \mathrm{z} 187\left(\mathrm{M}^{+}, 4\right)$, 131 (100); HRMS (EI, $20 \mathrm{eV}$ ) for $\mathrm{C}_{10} \mathrm{H}_{21} \mathrm{NO}_{2}\left(\mathrm{M}^{+}\right)$: calcd 187.1572, found 187.1556.

Compound 2 (562 mg, $3 \mathrm{mmol}), N$-hydroxy phthalimide (520 mg, $3.15 \mathrm{mmol}$ ) and triphenylphosphine (865 mg, $3.3 \mathrm{mmol})$ were dissolved in dry THF $(50 \mathrm{~mL})$ in a $100 \mathrm{~mL}$ dry round bottom flask. Then DIAD (diisopropyl azodicarboxylate, $0.62 \mathrm{~mL}, 3.15 \mathrm{mmol}$ ) was added dropwisely using a syringe at $0{ }^{\circ} \mathrm{C}$ under $\mathrm{N}_{2}$ atmosphere. After stirred for $1.5 \mathrm{~h}$, the solvent was removed on a rotary evaporator. The residue was dissolved in ethyl acetate and washed with water and of brine, then dried over anhydrous $\mathrm{MgSO}_{4}$ and concentrated. The crude oil was purified by flash column chromatography to afford compound 3 (917 mg, 92\%) as a white solid. M.p.: 92-94 ${ }^{\circ} \mathrm{C} ;[\alpha]^{20}{ }_{\mathrm{D}}\left(\mathrm{deg} \mathrm{cm} \mathrm{c}^{3} \mathrm{~g}^{-1} \mathrm{dm}^{-1}\right)$ $=+165.6^{\circ}\left(c=0.01 \mathrm{~g} \mathrm{~cm}^{-3}\right.$ in $\left.\mathrm{CHCl}_{3}\right) ;{ }^{1} \mathrm{H}-\mathrm{NMR}\left(400 \mathrm{MHz}, \mathrm{CDCl}_{3}\right) \delta 7.86-7.84(\mathrm{~m}, 2 \mathrm{H})$, $7.80-7.77(\mathrm{~m}, 2 \mathrm{H}), 7.67(\mathrm{br}, 1 \mathrm{H}), 4.82(\mathrm{dd}, J=9.0,3.9 \mathrm{~Hz} 1 \mathrm{H}), 3.30-3.23(\mathrm{~m}, 1 \mathrm{H})$, 3.00-2.94 (m, 1H), 2.17-2.05 (m, 1H), 1.88-1.79 (m, 3H), $1.12(\mathrm{~d}, J=6.6 \mathrm{~Hz}, 3 \mathrm{H}), 1.01$ 
$(\mathrm{d}, J=6.7 \mathrm{~Hz}, 3 \mathrm{H}), 0.97-0.93(\mathrm{~m}, 6 \mathrm{H}) ;{ }^{13} \mathrm{C}-\mathrm{NMR}\left(125 \mathrm{MHz}, \mathrm{CDCl}_{3}\right) \delta 170.47,164.05$, 134.91, 128.79, 87.08, 46.61, 41.90, 28.39, 24.82, 23.25, 21.81, 20.11; IR $\left(\mathrm{CHCl}_{3}\right) 3388$, $1735(\mathrm{C}=\mathrm{O}), 1664(\mathrm{C}=\mathrm{O}) \mathrm{cm}^{-1}$; LRMS (EI, $\left.20 \mathrm{eV}\right) \mathrm{m} / \mathrm{z} 332\left(\mathrm{M}^{+}, 2\right), 148(100)$; HRMS (EI, $20 \mathrm{eV}$ ) for $\mathrm{C}_{18} \mathrm{H}_{24} \mathrm{~N}_{2} \mathrm{O}_{4}\left(\mathrm{M}^{+}\right)$: calcd 332.1736, found 332.1716.

To a solution of compound $3(332 \mathrm{mg}, 1 \mathrm{mmol})$ in $\mathrm{CH}_{3} \mathrm{OH}(10 \mathrm{~mL})$ was added $\mathrm{NH}_{2} \mathrm{NH}_{2} \cdot \mathrm{H}_{2} \mathrm{O}(150 \mathrm{mg}, 3.0 \mathrm{mmol})$. A white precipitate appeared after 1 hour. After stirred at room temperature for 2.5 hours, the reaction mixture was concentrated under vacuo. The residue was dissolved in $\mathrm{CH}_{2} \mathrm{Cl}_{2}$ and was washed with $5 \% \mathrm{NaHCO}_{3}$ twice and then with brine. The organic layer was dried over anhydrous $\mathrm{Na}_{2} \mathrm{SO}_{4}$ and concentrated to provide a colorless oil, which was immediately used in the next step without further purification.

Freshly distilled $\mathrm{CH}_{2} \mathrm{Cl}_{2}(50 \mathrm{~mL})$ was added to a flask containing the above oil under nitrogen atmosphere, followed by the addition of HOAt (177 mg, $1.3 \mathrm{mmol})$, isophthalic acid $(83 \mathrm{mg}, 0.5 \mathrm{mmol})$, triethylamine $(0.14 \mathrm{~mL}, 1.0 \mathrm{mmol})$, and finally EDCI (447 mg, $1.5 \mathrm{mmol}$ ). After stirred overnight, the reaction mixture was diluted with $\mathrm{CH}_{2} \mathrm{Cl}_{2}$. The organic layer was washed with $5 \% \mathrm{NaHCO}_{3}$ and brine, then dried over anhydrous $\mathrm{MgSO}_{4}$ and concentrated. The crude oil was purified by flash column chromatography to afford compound $\mathbf{1}(200 \mathrm{mg}, 75 \%)$ as a white solid. M.p.: $176-178{ }^{\circ} \mathrm{C}$; $[\alpha]^{20}{ }_{\mathrm{D}}\left(\mathrm{deg} \mathrm{cm}^{3} \mathrm{~g}^{-1} \mathrm{dm}^{-1}\right)=+67.3^{\circ}\left(c=0.01 \mathrm{~g} \mathrm{~cm}^{-3}\right.$ in $\left.\mathrm{CHCl}_{3}\right) ;{ }^{1} \mathrm{H}-\mathrm{NMR}(600 \mathrm{MHz}$, $\left.\mathrm{CDCl}_{3}\right) \delta 10.43(\mathrm{~s}, 2 \mathrm{H}), 8.12(\mathrm{~s}, 1 \mathrm{H}), 8.07(\mathrm{t}, J=5.7 \mathrm{~Hz}, 2 \mathrm{H}), 8.04(\mathrm{~d}, J=7.8 \mathrm{~Hz}, 2 \mathrm{H})$, $7.57(\mathrm{t}, J=7.8 \mathrm{~Hz}, 1 \mathrm{H}), 4.40(\mathrm{dd}, J=9.5,3.4 \mathrm{~Hz}, 2 \mathrm{H}), 3.05-3.01(\mathrm{~m}, 2 \mathrm{H}), 2.91-2.88(\mathrm{~m}$, 2H), 1.86-1.62 (m, 8H), $0.92(\mathrm{~d}, J=6.6 \mathrm{~Hz}, 12 \mathrm{H}), 0.84(\mathrm{~d}, J=6.7 \mathrm{~Hz}, 6 \mathrm{H}), 0.78(\mathrm{~d}, J=$ 
$6.7 \mathrm{~Hz}, 6 \mathrm{H}) ;{ }^{13} \mathrm{C}-\mathrm{NMR}\left(75 \mathrm{MHz}, \mathrm{CDCl}_{3}\right) \delta 171.89,166.14,131.97,131.30,129.69$, 124.93, 85.60, 46.69, 41.15, 28.29, 24.85, 23.18, 21.81, 20.04, 19.99; IR $\left(\mathrm{CHCl}_{3}\right) 3332$, 3185, $1663(\mathrm{C}=\mathrm{O}) \mathrm{cm}^{-1}$; LRMS (EI, $\left.20 \mathrm{eV}\right) \mathrm{m} / \mathrm{z} 534\left(\mathrm{M}^{+}, 1\right), 131$ (100); HRMS (EI, 20 eV) for $\mathrm{C}_{28} \mathrm{H}_{46} \mathrm{~N}_{4} \mathrm{O}_{6}\left(\mathrm{M}^{+}\right)$: calcd 534.3417, found 534.3435.

\section{Determination of association constants by ${ }^{1} \mathrm{H}$ NMR titrations.}

The $\mathrm{CDCl}_{3}$ solution of $\mathbf{1}(1-5 \mathrm{mM})$ was titrated by the addition of concentrated $\mathrm{CDCl}_{3}$ solution of the anions (in the form of their tetrabutylammonium salts). To account for dilution effects, these anion solutions also contained receptor $\mathbf{1}$ at its initial concentration. The data were fit to a 1:1 binding profile according to the method of Wilcox (Wilcox, C. S. in Frontiers in Supramolecular Organic Chemistry and Photochemistry; Schneider, H.-J., Durr, H., Eds.; VCH; Weinheim, 1991) using changes in the aminoxy amide $\mathrm{NH}$ resonance in their ${ }^{1} \mathrm{H}$ NMR spectra $\left(\mathrm{K}\right.$, binding constant, $\mathrm{M}^{-1}$; $\left.\mathrm{D}, \Delta \delta_{\max }\right)$.
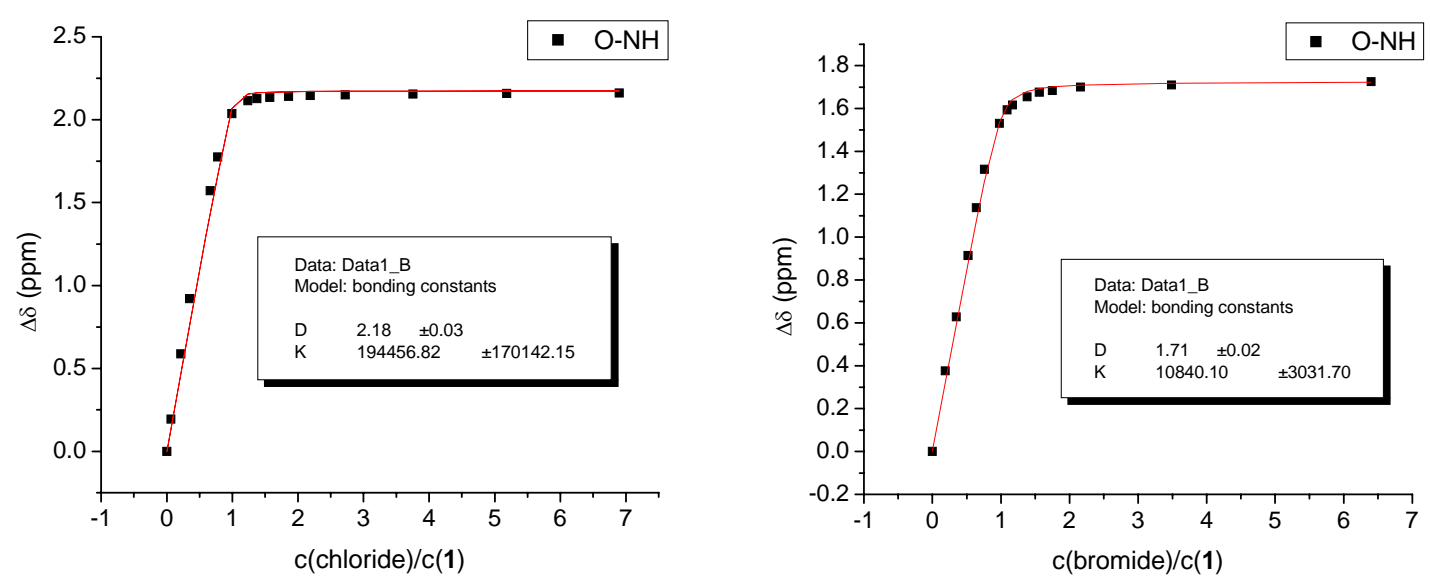

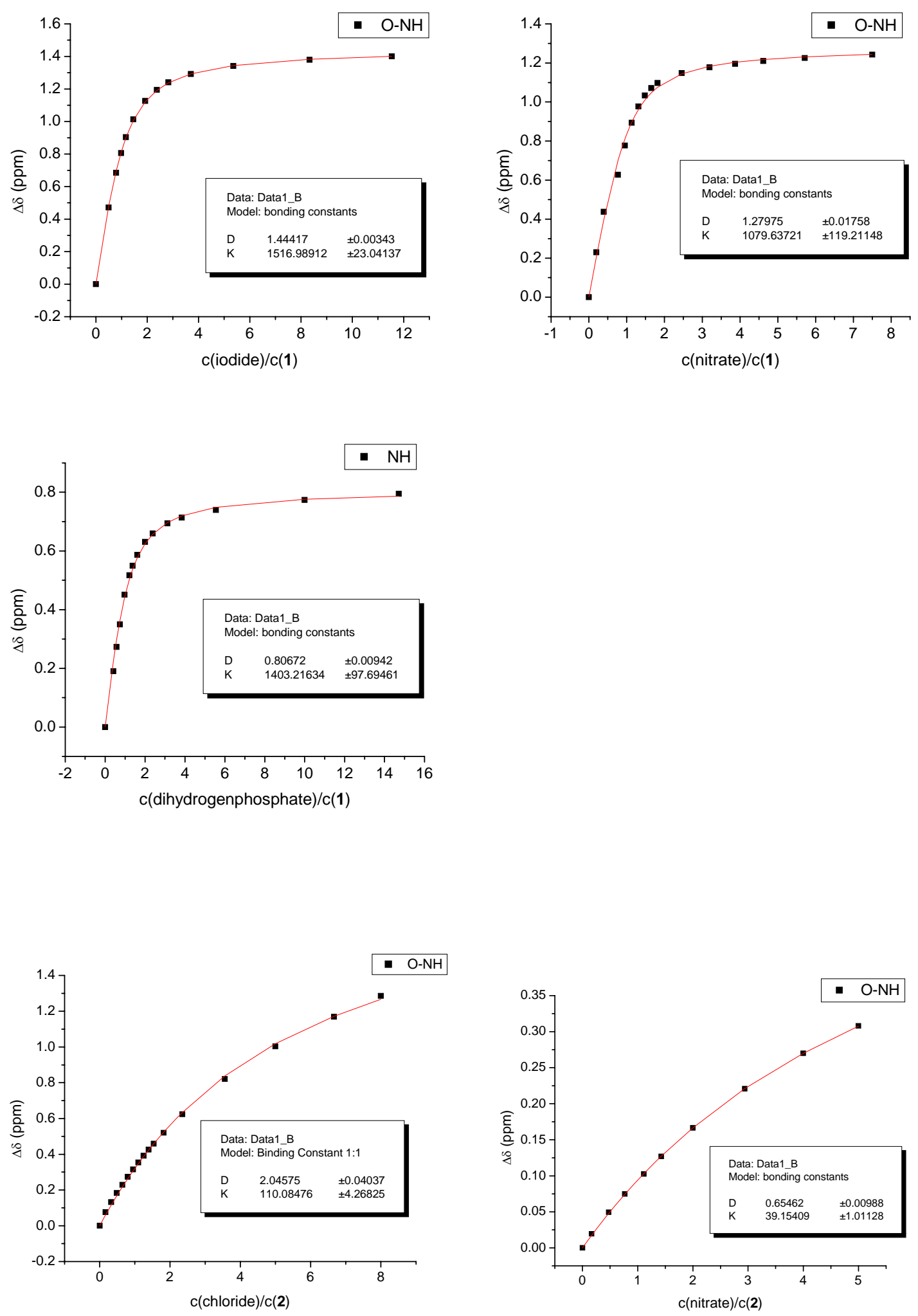

Studies of the stoichiometry of the receptor-anion complex for 1 and 2 (Job plots).

All recorded Job plots for 1 were found to exhibit maxima at $0.50 \pm 0.05$. This indicates that $\mathbf{1}$ forms a 1:1 complex with the anions concerned. $(\mathrm{x}=[\mathbf{1}] /([\mathbf{1}]+[$ anion $])$; 
$\Delta \delta=$ variation of the chemical shift of the observed proton)

$\mathbf{1}+\mathrm{Bu}_{4} \mathrm{NCl}$ in $\mathrm{CDCl}_{3}$

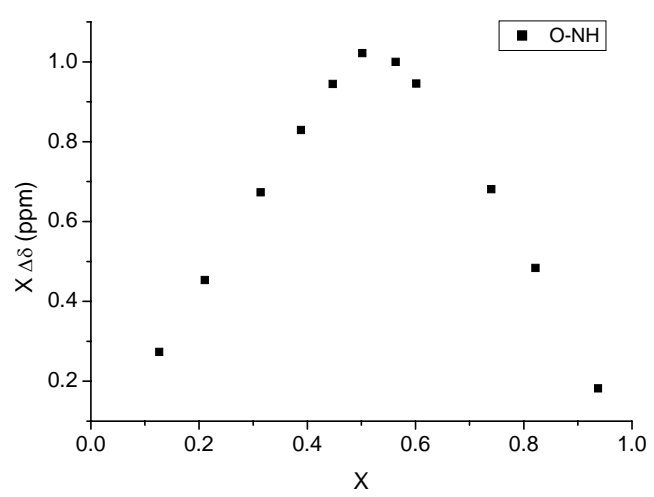

$\mathbf{1}+\mathrm{Bu}_{4} \mathrm{NI}$ in $\mathrm{CDCl}_{3}$

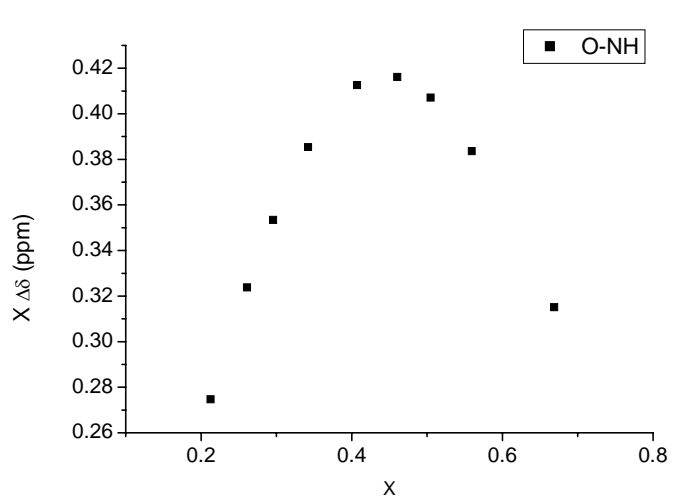

$1+\mathrm{Bu}_{4} \mathrm{NH}_{2} \mathrm{PO}_{4}$ in $\mathrm{CDCl}_{3}$

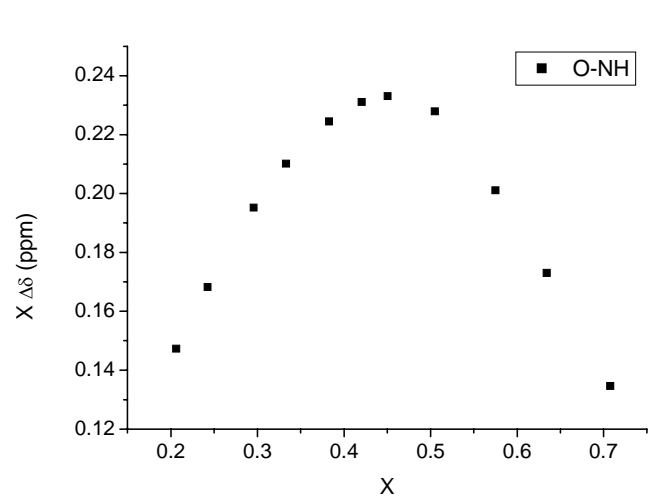

$\mathbf{1}+\mathrm{Bu}_{4} \mathrm{NBr}$ in $\mathrm{CDCl}_{3}$

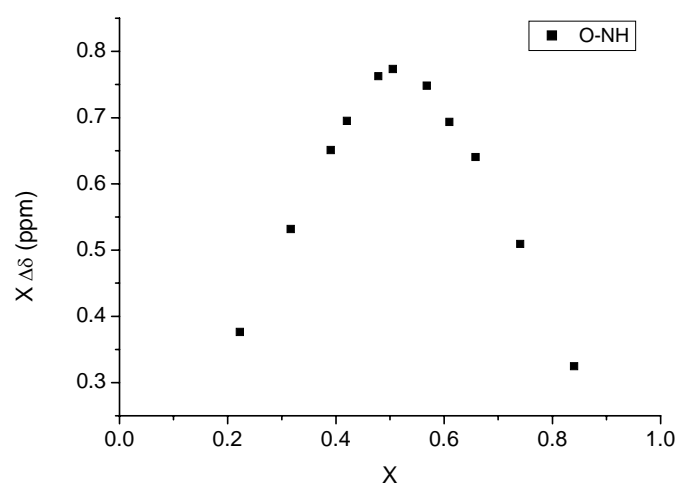

$\mathbf{1}+\mathrm{Bu}_{4} \mathrm{NNO}_{3}$ in $\mathrm{CDCl}_{3}$

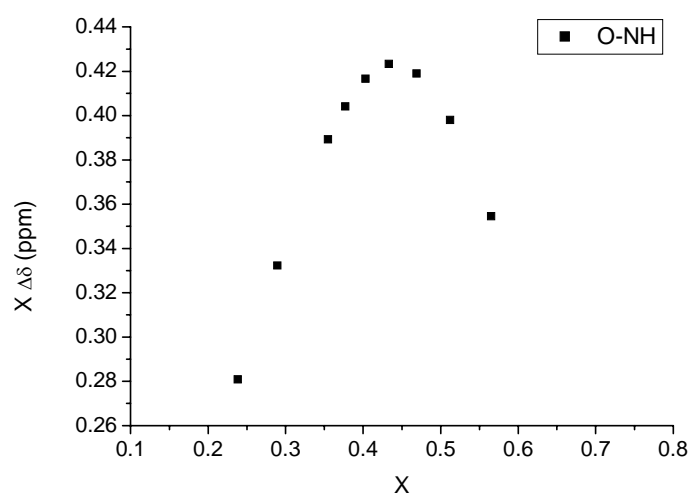

$2+\mathrm{Bu}_{4} \mathrm{NCl}$ in $\mathrm{CDCl}_{3}$

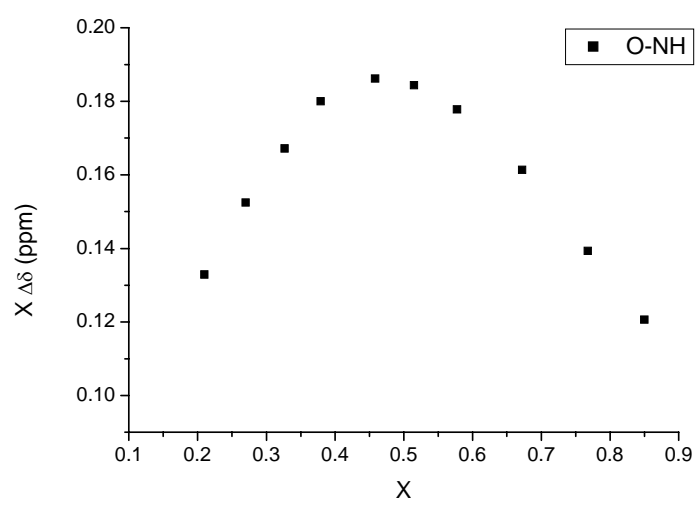


Liposome preparation: Egg yolk L- $\alpha$-phosphatidylcholine (EYPC, $91 \mathrm{mg}, 120 \mu \mathrm{mol}$ ) was dissolved in a $\mathrm{CHCl}_{3} / \mathrm{MeOH}$ mixture, the solution was evaporated under reduced pressure and the resulting thin film was dried under high vacuum for $3 \mathrm{~h}$. The lipid film was hydrated in $1.2 \mathrm{~mL}$ of solution $\mathrm{A}\left(200 \mathrm{mM} \mathrm{NaNO}_{3}, 0.5 \mathrm{mM} \mathrm{SPQ}\right)$ for $2 \mathrm{~h}$. During hydration, the suspension was submitted to 5 freeze-thaw cycles (liquid nitrogen, water at rt). The large multilamellar liposome suspension $(1 \mathrm{~mL})$ was submitted to high-pressure extrusion at $\mathrm{rt}(>21$ extrusions through a $0.1 \mu \mathrm{m}$ polycarbonate membrane afforded a suspension of large unilamellar vesicles (LUVs) with an average diameter of $100 \mathrm{~nm}$ ). The LUV suspension was separated from extravesicular dye by size exclusion chromatography (SEC) (stationary phase: Sephadex G-50, mobile phase: solution B: 20 $\mathrm{mM} \mathrm{NaNO} 3$ ) and diluted with the solution $\mathrm{B}$ to give a stock solution with a lipid concentration of $10 \mathrm{mM}$ (assuming 100\% of lipid was incorporated into liposomes).

Fluorescent Assay: Typically, $100 \mu \mathrm{L}$ of SPQ-loaded vesicles (stock solution) was suspended in $1.9 \mathrm{~mL}$ of solution $\mathrm{C}(200 \mathrm{mM} \mathrm{NaCl})$ and placed into a fluorimetric cell. SPQ emission at $430 \mathrm{~nm}$ was monitored with excitation wavelengths at $360 \mathrm{~nm}$. At $100 \mathrm{~s}$, $20 \mu \mathrm{L}$ of a $0.5 \mathrm{mM}$ THF solution of compound $\mathbf{1}$ was added through an injection port.

Single-channel recording on giant liposomes. Giant liposomes suitable for patch-clamp measurements were prepared according to a modified procedure ${ }^{23}$. Briefly, $20 \mathrm{mg}$ egg yolk L- $\alpha$-phosphatidylcholine (EYPC) (Avanti Polar Lipids) and cholesterol with a 10:1 molar ratio were dissolved in $2 \mathrm{~mL}$ of distilled water. The mixture was intermittently stirred with Vortex for $20 \mathrm{~min}$, and then sonicated for 10 min under nitrogen protection. The suspension was centrifuged at $160,000 \mathrm{~g}$ for $1 \mathrm{~h}$, and then the pellet was resuspended 
with $200 \mu \mathrm{L}$ of $10 \mathrm{mM}$ MOPS buffer ( $\mathrm{pH} 7.2)$ containing 5\% (w/v) ethylene glycol. The resuspended sample was deposited on a clean glass slide in $15 \mu \mathrm{L}$ aliquot and submitted to partial dehydration (3-6 h) in a desiccator containing anhydrous $\mathrm{CaCl}_{2}$ at $4{ }^{\circ} \mathrm{C}$. Before use, the sample was rehydrated for $10 \mathrm{~h}$ at $4^{\circ} \mathrm{C}$ by using $15 \mu \mathrm{L}$ of $200 \mathrm{mM}$ NMDG-Cl (or $\mathrm{KCl}$, depending on the measurements to be performed later) bath solution on a slide, which was placed in a closed Petri dish with a wet paper pad on the bottom. For patch-clamp measurements of giant liposomes, 1-3 $\mu \mathrm{L}$ of hydrated liposome suspension was dropped on a Petri dish and diluted with bath solutions. Single-channel $\mathrm{Cl}^{-}$currents through giant liposome membranes in presence of compound $\mathbf{1}$ were measured with inside-out patch configuration of the patch-clamp technique. Patch pipettes (resistance, 7-10 $\mathrm{M} \Omega$ ) were filled with internal pipette solution containing (in $\mathrm{mmol} / \mathrm{L}$ ): NMDG-Cl 200, HEPES 10, pH 7.2. The bath solution was composed of (in mmol/L) NMDG-Cl 200 (or $\mathrm{KCl} 200$ in ion selectivity test), HEPES 10, pH 7.2. When the seal resistance reached up to $10 \mathrm{G} \Omega$, single channel currents were recorded with EPC 9 patch clamp amplifier (HEKA Elektronik, Lambrecht/Pfalz, Germany) in voltage-clamp mode. Pipette and membrane capacitance were electronically compensated. Voltage-clamp protocol was applied with Pulse (HEKA). Single channel currents were digitized at 0.15 ms sampling interval, filtered at $2 \mathrm{kHz}$ and analyzed with TAC+TACFit (Bruxton Corporation, America).

\section{SPQ Assay of $\mathrm{Cl}^{-}$Transport in MDCK Cells}


Cell culture: MDCK cells were a generous gift of Dr. Leo LM Poon (Department of Microbiology, The University of Hong Kong, Hong Kong). The cells were cultured in DMEM supplemented with $10 \%$ FBS and $100 \mathrm{U} / \mathrm{ml}$ penicillin and $0.1 \mathrm{mg} / \mathrm{ml}$ streptomycin. Cells were grown in plastic culture flasks at $37^{\circ} \mathrm{C}$ in a $5 \% \mathrm{CO}_{2}$ humidified incubator and passaged every $3-5$ days.

SPQ assay of $\mathrm{Cl}^{-}$Transport: MDCK Cells were transferred to glass coverslips, cultured for 2-3 days, and then loaded with SPQ fluorescent dye by hypotonic loading. Briefly, cells were incubated at room temperature for 4 min with a 2:3 mixture of $\mathrm{Cl}^{-}$buffer (140 $\mathrm{mM} \mathrm{NaCl}, 5 \mathrm{mM} \mathrm{KCl}, 2 \mathrm{mM} \mathrm{CaCl} 2,1.0 \mathrm{mM} \mathrm{MgCl} 2,5 \mathrm{mM}$ Hepes, $10 \mathrm{mM}$ D-glucose, $\mathrm{pH}$ 7.4) and distilled $\mathrm{H}_{2} \mathrm{O}$, containing $5 \mathrm{mM}$ SPQ. The cells were preincubated with isosmotic $\mathrm{NO}_{3}{ }^{-}$buffer $\left(140 \mathrm{mM} \mathrm{NaNO}_{3}, 5 \mathrm{mM} \mathrm{KNO}_{3}, 2 \mathrm{mM} \mathrm{Ca} \text { (gluconate) }\right)_{2}, 1.0 \mathrm{mM}$ $\mathrm{Mg}$ (gluconate) $)_{2}, 5 \mathrm{mM}$ Hepes, $10 \mathrm{mM}$ D-glucose, $\mathrm{pH}$ 7.4) for 30 minutes to recover from the osmotic shock and allow the depletion of intracellular chloride. The glass coverslip was mounted in a chamber, which was arranged for continuous flow of buffer solutions at $25{ }^{\circ} \mathrm{C}$. At the beginning of the experiment, the cells were first perfused with nitrate buffer until the fluorescence was stable. Perfusion solution was then switched to $\mathrm{Cl}^{-}$buffer containing $1 \mu \mathrm{M}$ of compound $\mathbf{1}$ (dissolved in DMSO) or equal volume of DMSO. SPQ fluorescence was excited at $365 \pm 10 \mathrm{~nm}$. The fluorescence emission passed through a dichroic centered at $400 \mathrm{~nm}$, and a $420 \mathrm{~nm}$ long pass barrier filter. The emission was detected in most of the cases by an intensified CCD camera. The fluorescence images were acquired at variable intervals ( $2-8$ seconds). 